http://kitaibelia.unideb.hu/

ISSN 2064-4507 (Online) • ISSN 1219-9672 (Print)

(C) 2015, Department of Botany, University of Debrecen, Hungary

20 (1): 74-80; 2015

DOI: $10.17542 /$ kit.20.74

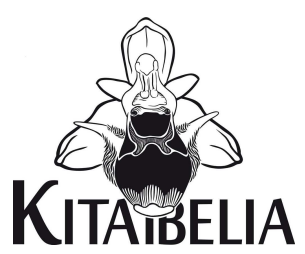

\title{
Néhány florisztikai adat Kötcse környékéről (Dél-Dunántúl, Nyugat-Külső-Somogy)
}

\author{
NAGY Timea \\ Pannon Egyetem, Georgikon Kar, Növénytudományi és Biotechnológiai Tanszék, H-8360 Keszthely, Festetics u. 7. \\ tima.nagy@gmail.com

\section{Some floristic data from surroundings of Kötcse (South Transdanubia, West Outer Somogy)}

\begin{abstract}
There are very few published and documented floristic data from the hills of the SW region of Hungary called 'Outer Somogy'. This paper present the occurrence data of 31 vascular plant species from the western part of this region. Among them 14 taxa are legally protected and further 17 taxa are sporadically occurring. The records were collected within the administrative area of villages Karád, Kereki, Kötcse, Nagycsepely, Szólád (Nezde) and Teleki. Most data were recorded in 2014. This is the first report on the occurrence of 1) Neotinea ustulata subsp. aestivalis in South Transdanubia, and 2) Epipactis microphylla and E. tallosii in Outer Somogy. Data provided on the occurrence of Cirsium boujartii on the northwestern border of the distribution area of this insufficiently known species.
\end{abstract}

Keywords: flora of Hungary, Outer Somogy, protected species, rare species, vascular plants

Összefoglalás - Írásomban Külső-Somogy egy kis szegletéből gyűjtött florisztikai adataimat közlöm. Az adatok többsége 2014-ből származik. Összesen 31 ritka, szórványosan előforduló vagy védett faj lelőhelyeit jegyeztem fel hat falu területéről [Karád, Kereki, Kötcse, Nagycsepely, Szólád (Nezde), Teleki]. A Dél-Dunántúl flórájára nézve új adat a Neotinea ustulata subsp. aestivalis előfordulása. Az Epipactis microphylla-nak és az E. tallosii-nak nem ismert korábbi adata Külső-Somogyból. A dolgozat a Cirsium boujartii új lelőhelyeit közli a faj elterjedésének északnyugati pereméről.

Kulcsszavak: Külső-Somogy, Magyarország flórája, ritka növényfajok, védett növényfajok,

\section{Bevezető}

Külső-Somogy dombvidékének flórájáról meglehetősen kevés publikált adat áll rendelkezésre (vö. például HoRvÁT 1943, illetve RozNER et al. 2011 és az ott hivatkozott irodalom). Különösen igaz ez Nyugat-Külső-Somogy általam bejárt vidékére, Kötcse környékére (1. ábra). A szűk környékről újabban PINKE et al. (2006), KIRÁLY (2007) és RoZNER et al. (2011) közölnek adatokat. PINKE et al. (2006) munkája az agrárkörnyezetben még megfigyelhető ritkább gyomfajokat (például Nigella arvensis, Vicia grandiflora, Thymelaea passerina, Ajuga chamaepitys, Camelina microcarpa, Centaurea cyanus) tartalmaz. Rozner et al. (2011) dolgozata ritka, védett fajokra koncentrál, így például Anacamptis pyramidalis, Anemone sylvestris, Aster amellus (Szólád, Nezde kültelek), Hepatica nobilis (Nagycsepely), Jurinea mollis, Neotinea tridentata, Orchis purpurea (Szólád, Nezde kültelek). Utóbbiakat magam is megfigyeltem az említett lelőhelyeken, ugyanakkor további adatokat is gyűjtöttem, melyeket KIRÁLY (2009) a környékre vonatkozóan ritkának vagy szórványosnak ítél. 


\section{Anyag és módszer}

A vizsgált terület a Külső-Somogyi dombság északkeleti negyedében fekszik, mindössze $9 \mathrm{~km}$ távolságra a Balaton déli partjától. A térség talajai legnagyobb részben agyagbemosódásos barna erdőtalajok, közepes mésztartalmúak, erősen kötöttek. Üledékes, löszös és márgás alapkőzeten alakultak ki. Jellemző a tájra a helyenként vastag (5-10 m) lösztakaró és a sűrű völgyhálózat (STIRLING 1996). A terület potenciális vegetációját a cseres tölgyesek jelentik (ZÓLYOMI 1968). A térséget ma a nagykiterjedésű szántóföldek mellett nagyrészt gyertyánostölgyesek, cseres-tölgyesek, akácosok, erdei- és feketefenyvesek uralják (KIRÁLY et al. 2008), változó állapotú kisebb-nagyobb gyep-fragmentumokkal együtt.

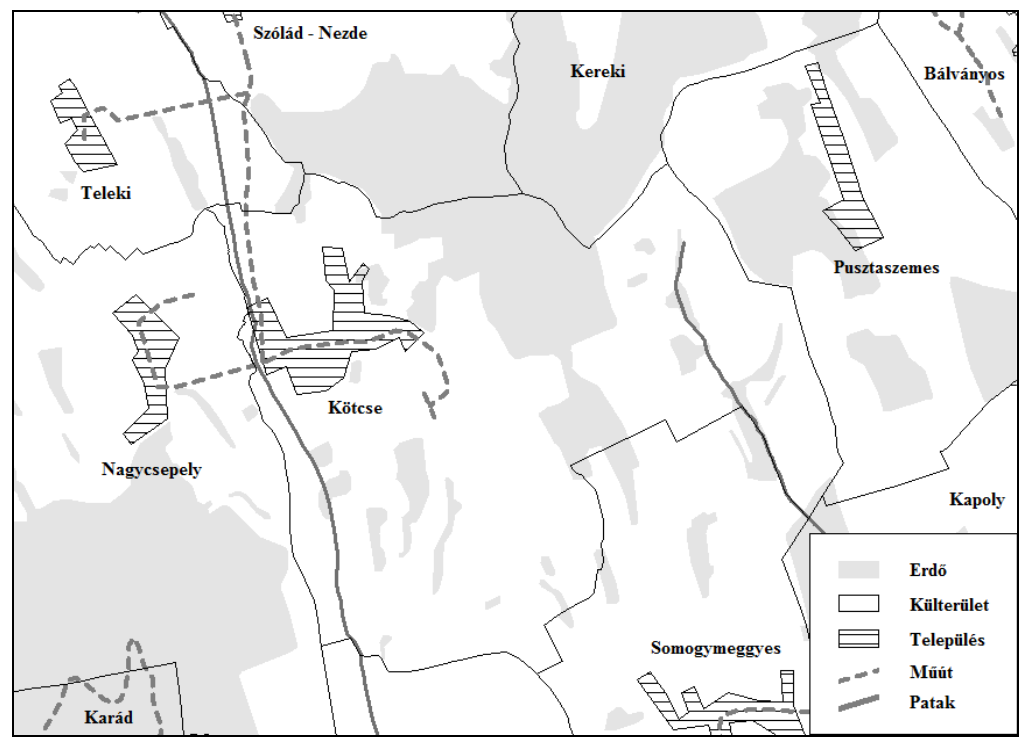

1. ábra. A vizsgált terület térképvázlata.

Fig. 1. The study area.

A térségben egyre intenzívebben telepítenek szőlőt (ami főleg a gyepterületek elvesztésével jár együtt). Az elmúlt évtizedek tapasztalatai alapján a kisparcellás szőlőművelést felváltja a nagyüzemi. Ezeken a nagy kiterjedésű parcellákon sajnos többnyire nem lejtőre merőlegesen, hanem a lejtő irányának megfelelően telepítik a sorokat. Ennek következménye a gyors talajerózió, amit magam is tapasztaltam a nyári felhőszakadások során.

A dolgozatomban közölt adatok legnagyobb részét a 2014-es terepbejárásaim során gyűjtöttem. Csak néhány adat származik a 2011-es és 2013-as évekből. Összesen 31 taxon (14 védett) előfordulási adatait foglalom össze Karád, Kereki, Kötcse, Nagycsepely, Szólád (Nezde) és Teleki községek területéről (1. ábra). A nevezéktannál a kosborfajok esetében MolnÁR V. (2011), a többi taxon esetében KIRÁlY (2009) múvét követem. A felsorolt adatoknál szerepeltettem a közép-európai flóratérképezés hálórendszerének kvadrátazonosítóit (NIKLFELD 1971). Amennyiben egy előfordulást herbáriumi példány dokumentál, azt külön jeleztem (H). A herbáriumi példányok a Pannon Egyetem Georgikon Karának Növénytudományi és Biotechnológiai Tanszékének Herbáriumában kerültek elhelyezésre. A dűlőnevek esetében elsősorban a III. katonai felmérés (1869-1887) [1] térképszelvényeit vettem figyelembe részletgazdagsága miatt, kisebb részben pedig az 1:10 000-es méretarányú EOTR topográfiai térképet. Az egyes lelőhelyek azonosításának megkönnyítése céljából minden adatot térképvázlaton jelölök (2. ábra). 


\section{Enumeráció}

Adonis vernalis L. - Szólád, Nezde kültelek: A Nezdei legelőn (Szólád-szőlőhegy), az Almántetőtől 1 km-re, északra a fából készült kilátó után, a földút nyugati felén, száraz Calamagrostis-os gyepben kis kiterjedésű területen bőven található [9273.1]. - A környéken nem ritka (vö. RozNER et al. 2011).

Ajuga chamaepytis (L.) Schreb. - Kötcse: A Bóka-völgy végében (Petőfi Sándor utca folytatása) a nagy kiterjedésű szőlőparcellák és a cseres-tölgyes közötti száraz gyepben néhány egyed [9273.1] (H). - HoRvÁT (1943) szerint közönséges. Úgy tűnik, mára megritkult (további adatait lásd: PINKE et al. 2006).

Bupleurum affine Sadler - Kereki: A kötcsei Csillogói kilátótól 700 m-re, északkeletre a Levelesi-erdő (Kereki erdő) szélén néhány szál [9273.1] (H). Nagycsepely: A Hársas-erdő keleti oldalán húzódó löszgyep-maradványban, a Zrínyi-tanyától 500 m-re délkeleti irányban pár szál [9273.3] (H). - A környékről nem találtam korábbi előfordulási adatát.

Calamintha mentifolia Host - Szólád: A Levelesi-erdő (Kereki erdő) és a Nezdei erdő (Nyésdei-erdő) találkozásánál lévő turista pihenőtől északra haladó erdei út mentén szórványosan [9273.1] (H). - A környékről nem találtam korábbi előfordulási adatát.

Campanula bononiensis L. - Szólád, Nezde kültelek: Az Almán-tetőtől a Nezdei-legelőre (Szólád-szőlőhegy) kiérve, egy kis kiterjedésű cserjésedő gyepben gyakori [9273.1] (H). Legközelebb Balatonszemesről ismert egy archív adata (MÁGocsY 1914).

Caucalis platycarpos L. - Nagycsepely: A Hársas-erdő mellett húzódó löszgyep-maradvány bolygatott részein, a Zrínyi-tanyától 500 m-re délkeleti irányban, bőven [9273.3]. - A környékről nem találtam korábbi előfordulási adatát.

Centaurea cyanus L. - Kötcse: Az újhegyi régi terményszárítótól (Vörös Csillag Tsz) a földúton haladva a faluba (Lochba), a cirokföld szélét kísérve jó néhány egyed [9273.3]; a Magyar utcából a Lóki-földekre (Lochba) kiérve a szántóföld szélén kis mennyiségben [9273.3]. - HoRvát (1943) szerint közönséges; mára valamelyest visszaszorult, de a környéken még nem ritka (vö. PINKE et al. 2006).

Cephalanthera damasonium (Mill.) Druce - Kötcse: A Csillogói kilátótól északra található telepített, fiatal cseres-tölgyesben elszórtan [9273.1]; a Csillogói kilátótól 250-300 m-re délnyugati irányban elhelyezkedő fiatal telepített cseres-kocsánytalan tölgyesben gyakori [9273.1]; az Újhegyi utca végén elterülő nagy kiterjedésű szőlőparcella északnyugati sarkánál lévő erdei fenyvesben tömeges [9273.1]; az Arany János utca folytatásában található Ódor pincétől 150 m-re, nyugatra lévő telepített cseres-tölgyesben gyakori [9273.1] (H). Kereki: A kötcsei Csillogói kilátótól 800 m-re északkeleti irányban a Levelesierdőben (Kereki erdő) cseres-kocsánytalan tölgyes alatt néhány egyed [9273.1]. - A környékről eddig igen kevés előfordulása ismert (vö. HoRvÁT 1943, RozNER et al. 2011).

Cephalanthera longifolia (L.) Fritsch - Kötcse: A Csillogói kilátótól északi irányban, telepített fiatal cseres-tölgyesben tömeges [9273.1]; a Csillogói kilátó mellett közvetlenül északi irányban található erdei fenyvesben néhány egyed [9273.1]; a Csillogói kilátótól 300-400 m-re, délnyugati irányban elhelyezkedő fiatal, telepített cseres-kocsánytalan tölgyesben gyakori [9273.1]. Szólád, Nezde kültelek: A kötcsei Csillogói kilátótól 600 m-re északra, a Nezdei erdő (Nyésdei-erdő) első nyugat-kelet irányú nyiladékán, csereskocsánytalan tölgyesben nem ritka [9273.1]. Kereki: A Csillogói kilátótól 800 m-re északkeletre, a Levelesi erdőben (Kereki erdő) cseres-kocsánytalan tölgyes alatt elszórtan [9273.1]; ugyanebben az irányban 1 km-re nem ritka [9273.1]. Karád: A Nagycsepelyről Karádra vezető erdészeti műút menti gyertyános-tölgyes erdő szélén, idős tölgyfák alatt néhány szál (Hosszu kopasz) [9273.3]. - A taxon pontosabb helymegjelölés nélkül ismert az általam is említett 9273.1 és a 9273.3 flóratérképezési kvadrátokból (MoLNÁR V. 2011). 
Cephalanthera rubra (L.) Rich. - Kereki: A Csillogói kilátótól 1 km-re, északkeletre a Levelesi erdőben (Kereki erdő) cseres-kocsánytalan tölgyes alatt ritka [9273.1], 2011-ben egyetlen virágzó hajtás. - A környékről eddig igen kevés előfordulása ismert (vö. HoRVÁT 1943, ROZNER et al. 2011).

Chamaecytisus austriacus (L.) Link - Nagycsepely: A Hársas-erdő mellett húzódó löszgyepmaradványban, a Zrínyi-tanyától 400 m-re délkeleti irányban tömeges [9273.3] (H). Legközelebb Balatonszemesről ismert egy archív adata (BoRBÁs 1900).

Chamaecytisus supinus (L.) Link - Szólád, Nezde kültelek: A Nezdei-legelőn (Szóládszőlőhegy), becserjésedő gyepben gyakori [9273.1] (H); a Levelesi-erdő (Kereki erdő) és a Nezdei erdő (Nyésdei-erdő) találkozásánál lévő turista pihenőtől 300 m-re Nezde felé (északra), az erdei út mentén néhány egyed [9273.1]. - Legközelebb Karádról és Szántódról ismertek archív adatai (HoRvÁT 1943).

Chrysopogon gryllus (L.) Trin. - Nagycsepely: A Zrínyi-tanyától 200 m-re, délkeletre a földút szélén a Hársas-erdő mellett néhány tő [9273.3]. - A környékről kevés adata ismert (HoRvÁT 1943).

Cirsium boujartii (Piller \& Mitterp.) Sch.Bip. - Kötcse: Az Újhegyből a Pázskum (akácos) felé tartó löszmélyutat övező löszpart tetején, a löszmélyút mindkét oldalán Crataegus monogyna-val, Prunus spinosa-val és Rosa canina-val cserjésedő gyepben, körülbelül $500 \mathrm{~m}$ hosszan meglehetősen gyakori [9273.1] (H), az állomány jelentős részét (a Páskum felé haladva a jobb löszparton) a kézirat benyújtásával egyidejűleg, 2014 őszén beszántották, helyére szőlőt terveznek telepíteni. Szólád, Nezde kültelek: Az egykor birkával legeltetett Nezdei-fáslegelőn (Szólád-szőlőhegy) becserjésedő és rendszeresen kaszált Botriochloa-s gyepben szórványos [9273.1]. - CSIKY et al. (2005) és SzABó et al. (2007) lényegében egy időben erősítik meg a faj dél-dunántúli előfordulását. Utóbbi közleményben a faj legészaknyugatibb ismert lelőhelyét jelzik (Ságvár), amelytől az itt közölt lelőhelyek közel 20 km-re, délnyugatra helyezkednek el a taxon elterjedésének peremén. A külső-somogyi löszvidéken valószínűleg többfelé előfordul.

Echium italicum L. - Kötcse: Az Újhegyből a Pázskum (akácos) és a Csillogói kilátó felé tartó löszmélyutat övező löszpartoldalakon, körülbelül $600 \mathrm{~m}$ hosszan gyakori [9273.1]. Legközelebb Kerekiből ismert archív adata (HoRVÁT 1943).

Epipactis helleborine (L.) Crantz - Kereki: A kötcsei Csillogói kilátótól 1 km-re, északkeletre a Levelesi erdő (Kereki erdő) cseres-kocsánytalan tölgyesei alatt 2 tő [9273.1]. - A környékről nem találtam korábbi előfordulási adatát.

Epipactis microphylla (Ehrh.) Sw. - Kereki: A kötcsei Csillogói kilátótól 900 m-re északkeleti irányban, a Levelesi (Kereki erdő) cseres-kocsánytalan tölgyes erdőben 7 egyed [9273.1]. Kötcse: Az Arany János utca végében elhelyezkedő Ódor pincétől északnyugatra, 200-250 m-re, telepített fiatal cseres-tölgyesben szórványosan [9273.1]. - A környékről nem találtam korábbi előfordulási adatát. Legközelebb a Balaton északi partjáról említik (MolnÁR V. 2011).

Epipactis tallosii A. Molnár \& Robatsch - Kötcse: A Völgy utca elején, az Antall kúria mögötti sűrü cserjésben, idős nyárfák alatt kis foltban 30 tő [9273.3]; az Antall kúriától 200 m-re, délnyugatra a Büdös-gáti-víz mentén 16 egyed [9273.3]; a Völgy utcában, az út menti füzfák alatt egy-két tő [9273.3]; Kötcse-Nagycsepely: a Mór-tanya közelében haladó erdei út mentén és közvetlenül az úton 36 tő [9273.3]; a Kötcse és Nagycsepely határán lévő régi kemping előtti kis kiterjedésű "tisztáson", a Mór-tanyához közel 16 egyed [9273.3] (H); az Újhegyben a Meggyesi utca 15-ös házszám hátsó udvarán, idős füz- és nyárfák alatt 4 egyed [9273.1]. - A környékről nem találtam korábbi előfordulási adatát. Legközelebb a KisBalatonról (MoLnÁR V. 2011) és az Aszófői-séd völgyéből említik (MÉSZÁROS \& SIMON 2009).

Erigeron acris L. - Szólád, Nezde kültelek: Az Almán-tetőtől 800 m-re, északra a Nezdeilegelőre (Szólád-szőlőhegy) kiérve, száraz gyepben néhány egyed [9273.1]. Kötcse: Az 
Újhegyből a Pázskum (akácos) irányába tartó löszpartoldalon 10 tő [9273.1]. - A környékről nem találtam korábbi előfordulási adatát.

Filago vulgaris Lam. - Nagycsepely: A Hársas-erdő mellett húzódó löszgyep-maradvány bolygatott részein, a Zrínyi-tanyától 600 m-re délkeleti irányban elszórtan [9273.3] (H). - A környékről nem találtam korábbi előfordulási adatát.

Hypericum montanum L. - Kereki: Kötcséről a Levelesi erdőbe (Kereki erdő) vezető út mentén, cseres-kocsánytalan tölgyesben a Csillogói kilátótól 800 m-re északkeleti irányban szórványosan [9273.1]. - Legközelebb Karádról ismert archív adata (HoRvÁt 1943).

Linum austriacum L. - Kötcse: Az újhegyi löszpartok meredek falán közepesen gyakori [9273.1]. - Legközelebb Szántódról ismert archív adata (HoRváT 1943).

Neotinea ustulata (L.) R.M.Bateman, Pridgeon \& M.W.Chase subsp. aestivalis (Kümpel) Jacquet \& Scappat. - Szólád, Nezde kültelek: Az egykor birkával legeltetett Nezdeifáslegelőn (Szólád-szőlőhegy), cserjésedő részeken egy idős Sorbus domestica közelében 2 tő [9273.1]. - A taxon dél-dunántúli előfordulási adata korábbról nem ismert. A Balaton északi részéről, a Bakonyból is csak a közelmúltban került elő (MÉszÁ́Ros \& SimoN 2009).

Neottia nidus-avis (L.) Rich. - Nagycsepely: A Bárány-rét és a halastó közti bükkös Vadaserdőben 2 tő [9272.4]. - Archív adata ismert Kötcséről (MÁGOCSY 1918) és Karádról (HoRvát 1943).

Orchis purpurea Huds. - Karád: A Nagycsepelyről Karádra vezető erdészeti műút menti gyertyános-tölgyes erdő szélén (Hosszu kopasz) idős tölgyek alatt egy-két tő [9273.3]. Kötcse: A Csillogói-hegyen a Porga pincétől déli irányban, rendszeresen kaszált gyepben néhány tő [9273.1]; a Porga pince mögött, fiatal tölgyes foltokban, száraz gyep-cserje mozaikban elszórtan [9273.1]; a Porga pince előtti, gyep-cserje mozaikban néhány virágzó tő és körülbelül 40 fiatal tőleveles állapotban lévő egyed [9273.1]; az Ódor pince előtti sűrű cserjés alá szorulva, árnyékos helyen gyakori [9273.1] (H); az Ódor pincétől északnyugati irányban 200-250 és 500 m-re, telepített fiatal cseres-tölgyesben tömeges [9273.1] (H). Szólád, Nezde kültelek: A Nezdei legelőn (Szólád-szőlőhegy), az Almán-tetőtől 1 km-re, északra a fából készült kilátó után, a földút nyugati felén, száraz Calamagrostis-os gyepben és cserjék alatt 31 tő [9273.1]. - Archív adata ismert Karádról és Kerekiből (HoRvát 1943), valamint pontos helymegjelölés nélküli aktuális adatai a következő flóratérképezési kvadrátokból: 9373.1, 9373.2, 9273.4 (MoLnÁR V. 2011).

Rapistrum perenne (L.) All. - Kötcse: A Sósdombi utcában, a Szabó pincétől 150 m-re, északra a szántóföld melletti mezsgyén néhány tő [9273.1]; a Lóki-földek (Loch) alatti Tekeres pusztánál patkó alakban húzódó akácos melletti parlagon elszórtan [9273.3]. Archív adata ismert Kerekiből (HoRvÁT 1943).

Rosa gallica L. - Kötcse: A Szabó pince (Sósdombi utca) mellett, az akáccal benőtt földút szélén néhány tő [9273.1]; az Arany János utca végén lévő Ódor pincétől 300 m-re, északnyugati irányban, a telepített cseres-tölgyes széle és a felhagyott szőlőparcella közt 1 m széles és 3 m hosszú sűrü sarjtelep [9273.1]. - Legközelebb Szántódról ismert archív adata (HoRvát 1943).

Samolus valerandi L. - Kötcse: A Völgy utcai nádasban, villanypásztor mentén lekaszált sávban 32 polikormon [9273.3] (H). - Legközelebb Balatonszárszóról ismert archív adata (BoROs 1936).

Silene viridiflora L. - Szólád: A kötcsei Csillogói kilátótól 400 m-re, északnyugatra a Nezdei erdő (Nyésdei-erdő, cseres-kocsánytalan tölgyes) melletti erdei úton néhány tő [9273.1]. Legközelebb Karádról és Kerekiből ismert archív adata (HoRvÁT 1943).

Sonchus palustris L. - Kötcse: Kötcse és Nagycsepely határán (Kötcséről Nagycsepelyre vezető aszfaltút), a Büdös-gáti-víz menti és a régi kemping előtti nádasban, a Mór-tanyához közel körülbelül 52 tő [9273.3] (H); a két falu határán, a Büdös-gáti-víz menti nádasban, a Nagy-tanya közelében több, mint 60 tő [9273.3]; a Völgy utcai nádasban (Völgy utca 11-el 
szemben) 22 tő [9273.3]. Teleki: A Telekibe vezető aszfaltút és a Büdös-gáti-víz kereszteződésénél körülbelül 50 tő [9273.1]; a Szólád-Teleki elágazásnál, az aszfaltút menti keskeny nádas sávban a Nezdei-pataknál néhány tő [9273.1], utóbbi élőhely a szennyvízelvezető rendszer kiépítéséhez kapcsolódó földmunkálatok következtében 2015re elpusztult. - Legközelebb Viszről ismert (RozNER et al. 2011).

Sorbus domestica L. - Szólád, Nezde kültelek: Régen birkával legeltetett, ma felhagyott, cserjésedő fáslegelőn néhány idős példány [9273.1]. - A környékről nem találtam korábbi előfordulási adatát.

Tordylium maximum L. - Kötcse: Az újhegyi löszpartoldaltól a Csillogói kilátó felé haladva a földút mentén elszórtan [9273.1]. - A környékrőll nem találtam korábbi előfordulási adatát.
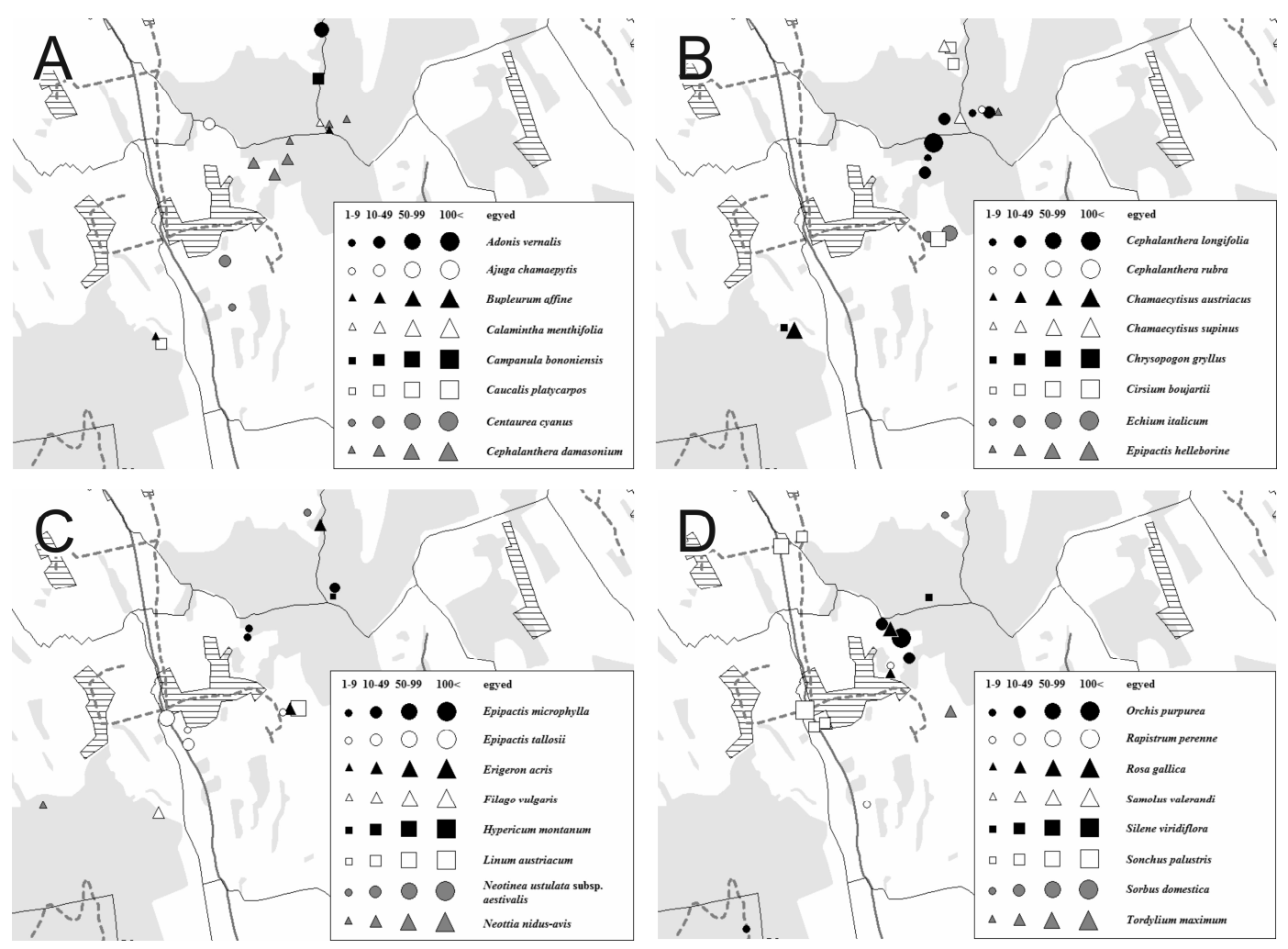

2. ábra. A vizsgált fajok elterjedése és állománynagyságai.

Fig. 2. Distribution and population sises of the studied taxa.

\section{Köszönetnyilvánítás}

Ezúton szeretném megköszönni Bódis Juditnak a kézirattal kapcsolatos hasznos tanácsait, valamint Takács Attilának a terepmunka való közremúködéséért.

\section{Irodalomjegyzék}

Borbás V. (1900): A Balaton flórája. A Balaton tavának és partmellékének növényföldrajza és edényes növényzete. - A Balaton tudományos tanulmányozásának eredményei I/2/2, Budapest, 432 pp.

Boros Á. (1936): Adatok Somogy vármegye flórájának ismeretéhez. - Vasi szemle 3: 79-86.

Csiky J., Farkas S., Király G., PÁl R., Purger D. \& Tóth I. Zs. (2005): A Cirsium boujartii (Pill. et Mitterp.) Schultz BiP. újrafelfedezése Magyarországon. - Flora Pannonica 3: 69-77. 
HoRvÁT A. O. (1943): Külsősomogy és környékének növényzete. - Borbásia 4: 1-70.

KIRÁLY G. (2007): Kiegészítések Külső-Somogy edényes flórájának ismeretéhez. - Somogyi Múzeumok Közleményei 17: 31-40.

KIRÁlY G. (szerk.) (2009): Új magyar füvészkönyv I-II., Magyarország hajtásos növényei, Határozókulcsok-Ábrák. - Aggteleki Nemzeti Park Igazgatóság, Jósvafő.

KIRÁLY G., MolnÁR Zs., BÖLÖNI J., CSIKY J. \& VojTKó A. (szerk.) (2008): Magyarország földrajzi kistájainak növényzete. - MTA ÖBKI, Vácrátót.

MÁGocsY-DiETZ S. (1914): Adatok a Balaton és környéke flórájának ismeretéhez. - Botanikai Közlemények 13: 117-127.

MÁGoCSY-DieTz S. (1918): Adatok a Balaton és környéke flórájának megismeréséhez. - Botanikai Közlemények 17: 17-35.

MÉszáros A. \& Simon P. (2009): Adatok Veszprém megye flórájához I. - Kitaibelia 17: 69-85.

MoLNÁR V. A. (szerk.) (2011): Magyarország orchideáinak atlasza. - Kossuth Kiadó, Budapest.

NikLFELD H. (1971): Bericht über die Kartierung der Flora Mitteleuropas. - Taxon 20: 545-571.

Pinke Gy., PÁl R., KirÁly G. \& SzEndRőDi V. (2006): Adatok Külső- és Belső-Somogy gyomflórájának ismeretéhez - Botanikai Közlemények 93: 53-68.

RozNer GY., MióKоVICS E. \& VIDÉKI R. (2011): Védett növényfajok előfordulási adatai Észak-Somogyban Natura Somogyiensis 19: 5-16.

STIRLing J. (1996): Kötcse monográfiája. - Kötcse község önkormányzatának kiadása, Kötcse, 16-18.

SZAbó I., KercSmÁr V., H. SzŐNYi É. \& L. NYÉKi E. (2007): Florisztikai és vegetáció tanulmány a Jaba völgyében (Külső-Somogy). - Somogyi Múzeumok Évkönyve (B) [2006]17: 69-82.

Zólyomi B. (1968): 5-ös térképlap része. - In: JAKucs P. (szerk.), Magyarország 1:200 000-es vegetációtérképe. Kézirat, MTA Földrajztudományi Kutató Intézet.

\section{Hivatkozott világháló oldalak}

[1]: http://mlp.archivportal.hu/ (Hozzáférés 2015. 01. 15.)

Beérkezett / received: 2015. 01. 15. • Elfogadva / accepted: 2015. 02. 22. 